sciendo Порівняльна професійна педагогіка 8(2)/2018

Comparative Professional Pedagogy 8(2)/2018

DOI: $10.2478 /$ rpp-2018-0022

PhD in Philology, Associate Professor, MARYNA IKONNIKOVA

Khmelnytskyi National University, Ukraine

Address: 11 Instytutska St., Khmelnytskyi, 29016, Ukraine

E-mail: ikonnikova@ukr.net

\title{
PROFESSIONAL TRAINING OF FOREIGN LANGUAGE TEACHERS IN THE USA: BASED ON THE EXPERIENCE OF LEWIS UNIVERSITY
}

\section{ABSTRACT}

The paper deals with professional training of future foreign language teachers in the USA based on the experience of Lewis University. As evidenced by research findings, the scope of foreign language education in the USA is rather broad, since they attempt to promote both traditional and critical languages in the context of developing translingual and transcultural competences. Based on the example of Lewis University, we have characterized professional training of future foreign language teachers, who major in the Spanish language. The obtained results prove that the programme content is extremely practice-oriented and designed to fulfill personal needs of every student; the programme curriculum is not overwhelmed with theoretical paradigms and foreign language students can participate in different activities and fully comprehend the realities of schools and the education process. It has been found that while mastering the programme, they are able to acquire the professional knowledge, skills and abilities they will definitely need in practice. The positive aspects of Lewis University's foreign language education programme have been determined. They are the following: practice-oriented approach to professional training of future foreign language teachers; an optimal selection of professional education courses and electives, as well as effective clinical practice; the assessment and evaluation of foreign language students' results during and after undergoing clinical practice from different perspectives, namely, organization, content, specifics; the implementation of the inclusive education component into the content of the programme curriculum; the fulfillment of different personal, learning and occupational needs of future foreign language students. It has been concluded that the outlined positive aspects of American experience in providing professional training of future foreign language teachers based on the experience of Lewis University can be implemented into the system of foreign language education in Ukraine in order to enhance quality and efficiency of these specialists' training at Ukrainian higher education institutions.

Keywords: foreign language education, foreign language teacher, Bachelor of Arts, programme, Lewis University, the USA, Ukraine.

\section{INTRODUCTION}

The expansion of Ukraine's international relations and its integration into the global community have rather popularized foreign languages in the country. The government and citizens require foreign language specialists, who have profound professional and interdisciplinary knowledge, comprehend the changes occurring in science, technologies and are knowledgeable about philosophical, psychological, pedagogical and methodological aspects of foreign languages teaching and learning, namely, highly- 
qualified specialists, who are competitive in the modern labour market locally and internationally. Nowadays, foreign languages fully realize their functions as a means of communication, mutual understanding, influence and interaction among individuals, a mechanism for familiarizing with other cultures and developing individuals' intellectual abilities, their critical, logical and analytical thinking through analysis, synthesis, conclusions, comparisons, generalizations, various types of memory (operational, semantic, involuntary, voluntary) in order to develop foreign language competence.

The integration of Ukraine into the global educational space calls for a thorough study and analysis of foreign experience in organizing the education system, including higher education. One of the topical trends in studying foreign experience is professional training of modern foreign language teachers at universities of the United States of America. N. Bidyuk (2013) indicates that in the analyzed context the achievements of the USA in the organization of the education system are of great scientific interest, since the country is the centre of global linguistics and has gained international recognition for high efficiency of language specialists' professional training. Therefore, the multiaspect and objective study of the most prominent pedagogical achievements of American education will contribute to widening scientific views of Ukrainian scholars with new ideas in order to justify conceptual principles, to transform the curriculum content, to improve forms, methods and technologies in professional training of language specialists (Bidyuk, 2013, p. 106).

In addition, research relevance is reinforced by the fact that American and Ukrainian foreign language education shares a common goal, namely, to prepare a highly educated foreign language teacher, who is professionally mobile and ready for continuing development of professional and personal qualities.

So, the significance of the problem under study is determined by potential opportunities for using positive experience of the American education system, characterized by flexibility, variability, the ability to quickly adapt to the changing needs of modern postindustrial, information communities.

\section{THE AIM OF THE STUDY}

The paper aims to characterize professional training of future foreign language teachers in the USA based on the experience of Lewis University and to outline positive aspects of this experience so that they may be effectively implemented into the system of foreign language education in Ukraine.

\section{THEORETICAL FRAMEWORK AND RESEARCH METHODS}

Ukrainian and foreign scholars have been actively conducting researches on professional training of foreign language teachers. Of scientific and practical value are the researches by N. Bidyuk, L. Bazyl, V. Korniienko, O. Martyniuk, L. Matsko, N. Mukan, N. Paziura, O. Semenog, T. Symonenko, I. Sokolova, O. Zinovatna et al. In the context of studying the US experience, researches by such American scholars as K. Bauer, J. Bennett, D. Brakke, R. Brecht, A. Brew, B. Clark, M. Crowe, R. Erickson, E. Jewell, C. Kardash, J. Kinkead et al. should be taken into account. Researchers indicate the growing interest in foreign languages of the US government and the public, as well as the increased attention to mastering this subject in both secondary and higher education institutions. The current growth in quality of foreign languages teaching in the United States is largely facilitated by optimal using modern forms, methods and means of instruction in the system of foreign language teachers' professional training.

It must be noted that in the process of its development, foreign language education in the United States has already solved many of the problems modern Ukrainian education 
is currently facing, namely, differentiation and individualization of higher education, the use of modern innovative teaching and learning technologies, the introduction of alternative programmes for professional training in foreign languages into the practice of higher education institutions. The latter have accumulated a rich historical experience in applying humanistic approach to professional training of future foreign language teachers. The search for ways to enhance quality of such specialists' professional training under the conditions of higher education institutions has become nationwide and is actively supported by the US government.

However, there are still some challenges the American society is facing nowadays in the context of foreign languages demand and supply. Based on the data presented in the Report of the Modern Language Association (MLA) Ad Hoc Committee on Foreign Languages (2007), one could observe rather a dynamic, rapidly changing American environment marked by a sense of crisis around what came to be called the nation's language deficit. In addition, initiatives in critical languages began multiplying in educational institutions all over the United States. Government language schools scrambled to redefine priorities and mount new programs. MLA data show that college and university enrollments in foreign languages increased. As a result, shortages of qualified, trained teachers of foreign languages became more acute than ever before. Legislative proposals to address the deficit in language and international expertise began appearing in Congress (Modern Language Association, 2007).

R. Brecht (2015) proves that there are clear and encouraging signs indicating growing support for language and language education in the US, namely, an emerging and articulated rationale for languages at the societal and individual level; popular attitudinal changes and a decade of innovative investments; revolutionary advances in scientific research and information and communication technologies (ICTs) as applied to language learning and use; clear public promotion of language by organizations, businesses and academies; proven supply from programs across the academic, government, industry, heritage and Overseas/NGO sectors; and, rising demand in all 5 sectors and across society for language skills.

The aspects mentioned above have influenced our choice of the topic for the research, since American higher education institutions are the very centers of personal development enhancement and strive to adapt to all challenges global and American community are facing presently. Indeed, Lewis University applies unique approaches to preparing future foreign language teachers to live in today's and tomorrow's globalized world and function effectively as global citizens, since foreign language study is inseparable from high-quality liberal education and assist foreign language students in eliminating narrow ethnocentrism, which may occur due to monolingual education (Lewis University, 2018a).

To achieve the aim of the research and outline positive aspects of Lewis University' experience in organizing professional training of future foreign language teachers, we have applied such scientific methods as theoretical analysis, generalization, individualization and systematization.

\section{RESULTS}

To begin with, theoretical analysis of relevant scientific and methodological sources has shown that the main requirements for future foreign language teachers in the USA are the following: the ability to transform the acquired knowledge into specific suggestions, to reveal creativity and flexibility while applying innovative knowledge, 
experience and teaching and learning methods; to implement methodology of scientific researches and demonstrate methodological culture; to generate and optimize new ideas and efficient solutions; to conduct analytical studies, to identify patterns and relationships between modern processes of linguistics development; to use fundamental and applied aspects of scientific theory; to work independently with scientific, educational, methodological and reference literature; to work effectively with innovative electronic resources and teaching and learning technologies to solve applied linguistic tasks; to summarize the findings of researches; to gain relevant professional experience through independent acquisition of professional knowledge and skills during internship and placements; to interact with other specialists in interdisciplinary teams; to optimally use experience of intercultural interaction, etc. (Bauer, \& Bennett, 2013).

Therefore, the MLA suggests that the language major should be structured to produce a specific outcome: educated speakers who have deep translingual and transcultural competence. Advanced language training often seeks to replicate the competence of an educated native speaker, a goal that postadolescent learners rarely reach. The idea of translingual and transcultural competence, in contrast, places value on the ability to operate between languages. Students are educated to function as informed and capable interlocutors with educated native speakers in the target language. They are also trained to reflect on the world and themselves through the lens of another language and culture. They learn to comprehend speakers of the target language as members of foreign societies and to grasp themselves as Americans - that is, as members of a society that is foreign to others. They also learn to relate to fellow members of their own society who speak languages other than English (Modern Language Association, 2007).

Lewis University has implemented the principles of the Lasallian education philosophy to make foreign language study available and efficient for every student. It must be mentioned that in the context of Lasallian education philosophy, teaching practice should focus on student learning, effective communication, respect, knowledge of the subject and sound teaching and learning theory, holding high expectations of their students, giving praise more readily than correction, holding the individual student in high regard and acting as a role model for the students (St. Joseph's Institution, 2018). The University aims to provide their students with quality instruction leading to immediate practical outcomes. Consequently, all instructors of the University's Foreign Language Department apply innovative approaches to teaching and learning foreign languages, which are facilitated by the most effective approaches to second language acquisition. The University's foreign language programmes focus on oral communication and do not overwhelm their students with an abundance of theoretical material, grammar rules, exercises and long vocabulary lists.

Developed in 2004, the University's foreign language programme is based on a wide variety of different world languages, both traditional or commonly taught languages (Spanish, French, German, Italian), as well as critical and less-commonly taught languages (Arabic, Chinese, Japanese, Polish, and Russian). Moreover, most of the Department's faculty members are native speakers of the languages they teach and are able to provide their students with cultural insights.

In order to characterize professional training of future foreign language teachers in the USA, we will characterize the Foreign Language Education, B.A. (A K-12 Licensure), offered by Lewis University. It must be noted that this programme is designed for the candidates who intend to teach foreign language in public and private sector schools, in 
sciendo Порівняльна професійна педагогіка 8(2)/2018

Comparative Professional Pedagogy 8(2)/2018

particular Spanish. Thus, the main features of the programme are 1) innovations that cover the material for earning a bachelor's degree with a major in Spanish, as well as preparation for licensure to teach Spanish at the K-12 setting, 2) teaching practices by learning instructional techniques and their application by observing K-12 classrooms and interacting with students, 3) the benefit of Lewis University's interaction with regional school districts for future employment, 4) a welcoming community filled with people dedicated to helping one's academic and educational growth, 5) the use of the most advanced teaching and learning technologies (Blackboard, iPads, Smartboards, etc. In addition, all University's programmes are approved by the Illinois State Board of Education and are fully accredited by the National Council for Accreditation of Teacher Education (NCATE), the premier accrediting agency for colleges of education.

Thus, the degree requirements cover professional education courses for foreign language licensure, professional educator license, recommended electives, advanced writing requirement (total credit hours - 128, major credit hours - 38) (Lewis University, 2018b).

The courses onprofessional education for foreign language licensure include Field Experience 1, 2: Secondary, Special Methods for Teaching Foreign Language to Elementary Grades, Adolescents, Methods for Teaching Reading in the Content Areas to Adolescents, Integrating Educational and Assistive Technology in the Classroom, Characteristics and Development of the Adolescent Learner, Instructional Strategies and Learning Communities for Adolescents, Pedagogy and Assessment for Effective Instruction, Clinical Practice and Seminar: Foreign Language, Foundations of Teaching Bilingual and English Language Learners, Exceptional Learners in Inclusive Communities. Professional educator license implies registering for six hours of Special Methods Instruction. The recommended electives consist of Curriculum and Instruction in the Middle School, Communication for Teachers. The advanced writing requirement is fulfilled by successful completion of Clinical Practice and Seminar: Foreign Language (Lewis University, 2018c).

Within this research, we would like to describe in detail certain courses mentioned above. First of all, Field Experience 1 implies completing a minimum of 50 hours in a public or private school where students can participate in the development and delivery of lessons plans. Also they are encouraged to explore theories of classroom management, to analyze classroom scenarios and formulate a plan that supports a positive learning community. Importantly, they should reflect on their educational experiences, field experience observations and current research in education during reflective practice (Lewis University, 2018d). At the same time, Field Experience 2 motivates students to analyze effective teaching practices, examine assessment data, work with families, etc. (Lewis University, 2018e).

Given the rapid promotion of inclusive education in Ukraine, it is imperative to describe the course on Exceptional Learners in Inclusive Communities. Thus, it aims to provide future foreign language teachers with knowledge, skills and the main principles required to identify and instruct exceptional learners in inclusive classroom settings. The course content and assessment focus on the characteristics of exceptional learners, the processes of identifying them for appropriate services, collaboration with parents and professional colleagues and research-based approaches for designing inclusive classroom settings and instructional/behavioural/assessment strategies and support for exceptional learners. This course also includes a five-hour field experience (Lewis University, 2018g).

Special attention should be paid to clinical practice. In particular, it lasts for 15-16 weeks, during which students can engage in teaching in two settings, namely, the K-8 level 
and high school level. Future foreign language teachers should be fully responsible for their duties as classroom teachers. Thus, they should be able to develop, deliver, assess instruction; grade and evaluate students; manage their classroom; communicate and interact with families, school personnel; interpret the data related to student learning. It must be noted that during the practice students are assisted by mentor teachers, University supervisors and content area specialists through observation and feedback (Lewis University, 2018f).

\section{CONCLUSIONS}

So, as we can see from research findings, the scope of foreign language education in the USA is rather broad, since they attempt to promote both traditional and critical languages in the context of developing translingual and transcultural competences. Based on the example of Lewis University, we have characterized professional training of future foreign language teachers, who major in the Spanish language. The obtained results prove that the programme content is extremely practice-oriented and designed to fulfill personal needs of every student, since the programme curriculum is not overwhelmed with theoretical paradigms and foreign language students can participate in different activities and fully comprehend the realities of schools and the education process. Thus, the professional education courses for foreign language licensure include only those topics, which future language teachers are truly interested in, namely, development and delivery of lessons, assessment and evaluation, reflection. While mastering these courses, they are able to acquire those professional knowledge, skills and abilities they will definitely need in practice. Special attention should be also paid to mastering the aspects of inclusive education. Considering the global trends in promoting the rights of learners with special educational needs, future foreign language students must be aware of the methods and techniques required to identify and instruct exceptional learners. Another important aspect in Lewis University's experience is providing future foreign languages teachers with the opportunity to undergo clinical practice and apply the acquired knowledge and skills in real educational settings. In our opinion, the fact that three different specialists assess and evaluate foreign language students' results indicates promoting sustainable development of future teachers' professional training, since these specialists are able to focus on different aspects of students' activities simultaneously, express different views from different angles and assist students in understanding the essence of effective teaching.

Therefore, the positive aspects of Lewis University's foreign language education programme are the following: teachers;

1) practice-oriented approach to professional training of future foreign language

2) an optimal selection of professional education courses and electives, as well as effective clinical practice;

3 ) the assessment and evaluation of foreign language students' results during and after undergoing clinical practice from different perspectives, namely, organization, content, specifics;

4) the implementation of the inclusive education component into the content of the programme curriculum;

5) the fulfillment of different personal, learning and occupational needs of future foreign language students.

The outlined positive aspects of American experience in organizing professional training of future foreign language teachers based on the experience of Lewis University 
sciendo Порівняльна професійна педагогіка 8(2)/2018

Comparative Professional Pedagogy 8(2)/2018

can be implemented into the system of foreign language education in Ukraine in order to enhance quality and efficiency of these specialists' professional training at Ukrainian higher education institutions.

Therefore, the prospects for further studies include studying European innovative experience in enhancing quality of foreign language education.

\section{REFERENCES}

1. Bauer, K. W., \& Bennett, J. S. (2013). Alumni perceptions used to assess undergraduate research experience. The Journal of Higher Education, 74 (2), 210-230.

2. Bidyuk, N. M. (2013). Kontseptualni zasady profesiinoi pidhotovky fakhivtsiv z prykladnoi linhvistyky u SShA. Porivnialna profesiina pedahohika, 2, 105-115.

3. Brecht, R. (2015). America's languages: challenges and promise. Retrieved from https://www.amacad.org/multimedia/pdfs/AmericasLanguagesChallengesandPromise.pdf.

4. Modern Language Association. (2007). Foreign languages and higher education: new structures for a changed world. Retrieved from https:/www.mla.org/Resources/Research/ Surveys-Reports-and-Other-Documents/Teaching-Enrollments-and-Programs/ForeignLanguages-and-Higher-Education-New-Structures-for-a-Changed-World.

5. Lewis University. (2018a). Foreign Language Department. Message from the Director. Retrieved from http://www.lewisu.edu/academics/foreignlang/index.htm.

6. Lewis University. (2018b). Foreign language education, B.A. (A K-12 licensure). Retrieved from http://www.lewisu.edu/academics/foreignlanguageeducation/index.htm.

7. Lewis University. (2018c). Foreign language education / Bachelor of Arts. Degree requirements. Retrieved from http://lewisu.smartcatalogiq.com/Undergrad-20182019/undergraduate-catalog/College-of-Education/Education-Majors/Foreign-LanguageEducation.

8. Lewis University. (2018d). SCED-2000 Field Experience 1: Secondary. Retrieved from http://lewisu.smartcatalogiq.com/en/Undergrad-2018-2019/Undergraduate-Catalog/ Course-Descriptions/53-Education/200/53-200.

9. Lewis University. (2018e). SCED-2000 Field Experience 2: Secondary. Retrieved from http://lewisu.smartcatalogiq.com/en/Undergrad-2018-2019/UndergraduateCatalog/Course-Descriptions/53-Education/300/53-300.

10. Lewis University. (2018f). SCED-48300 Clinical practice and seminar: foreign language. Retrieved from http://lewisu.smartcatalogiq.com/en/Undergrad-2018-2019/ Undergraduate-Catalog/Course-Descriptions/53-Education/400/53-483.

11. Lewis University. (2018g). SPED-35700Exceptional learners in inclusive communities. Retrieved from http://lewisu.smartcatalogiq.com/en/Undergrad-2018-2019/ Undergraduate-Catalog/Course-Descriptions/54-Education/300/54-357.

12. St. Joseph's Institution. (2018). Principles of Lasallian education. Retrieved from http://www.sji.edu.sg/about-sji/principles-of-lasallian-education. 